\title{
Intra-articular mesenchymal stem cell therapy on a joint capsule rupture in a horse -
}

\section{Case report}

\author{
Aplicação intra articular de células tronco mesenquimais no tratamento de ruptura de cápsula \\ articular em equino - Relato de caso \\ Aplicación intra-articular de células madre mesenquimales en el tratamiento de la ruptura de la \\ cápsula articular en equinos - Reporte de caso
}

Recebido: 08/09/2021 | Revisado: 14/09/2021 | Aceito: 16/09/2021 | Publicado: 18/09/2021

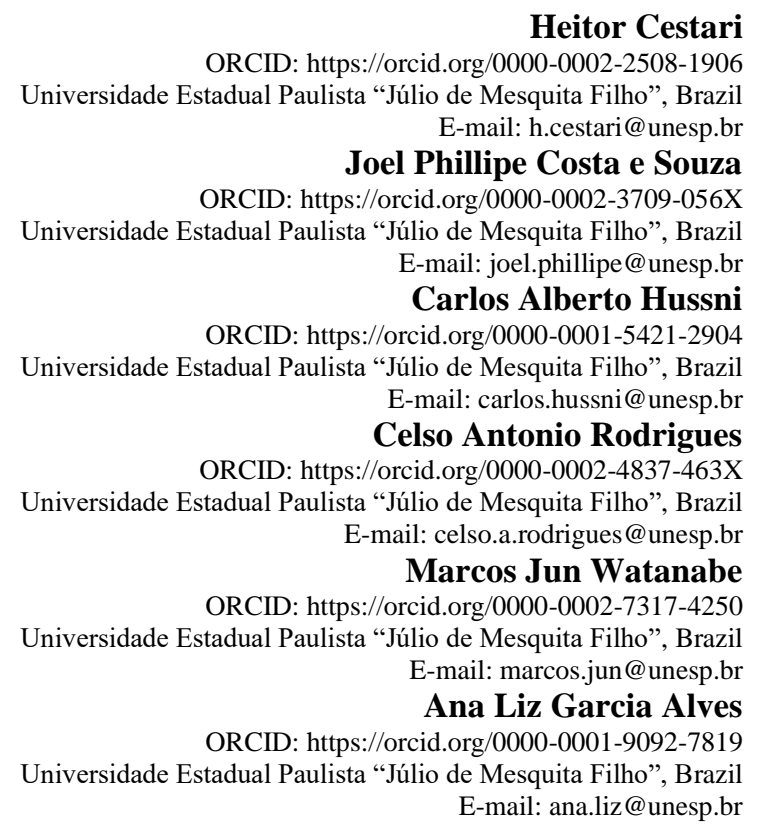

\begin{abstract}
Joint capsule rupture is an uncommon pathology that leads to intense pain, lameness and is related to the athletic performance impossibility of the animal. This pathology presents controversial therapeutic protocols in the equine clinic and surgery. Therefore, this study aimed to report the use of mesenchymal stem cells associated with arthroscopy and rehabilitation to improve the treatment of joint capsule rupture in equine. A three-year-old, male, Quarter Horse, presenting grade 5 lameness, with four months of evolution, was diagnosed with tibiotarsal joint capsule rupture. The patient underwent arthroscopic surgery, received an intra articular application of mesenchymal stem cells, and a rehabilitation protocol was performed. One year after the treatment and rehabilitation, the horse reestablished its athletic performance, thus indicating the success of the therapy using mesenchymal stem cells associated with surgical treatment and rehabilitation.
\end{abstract}

Keywords: Tibiotarsal joint; Lameness; Totipotent cells; Adjuvant therapy.

\section{Resumo}

A ruptura de capsula articular em equinos é uma enfermidade pouco comum que leva a dor intensa, claudicação e está relacionada a impossibilidade de desempenho atlético do animal. Esta enfermidade apresenta protocolos terapêuticos ainda controversos na clínica e na cirurgia de equinos. Diante disso, objetivou-se relatar o uso de células tronco associado à artroscopia e a reabilitação para o tratamento de ruptura de cápsula articular em equino. Para tal, acompanhou-se o caso de um equino quarto de milha de três anos de idade apresentando claudicação intensa com quatro meses de evolução, sendo diagnosticado com ruptura de capsula articular da articulação tibiotársica. O paciente foi submetido à artroscopia, 
recebeu uma aplicação de células troco mesenquimais via intra articular, associado a um protocolo de reabilitação. Após um ano de tratamento e reabilitação o animal reestabeleceu o desempenho atlético de baixa intensidade, demonstrando o sucesso da terapia com células tronco mesenquimais associado ao tratamento cirúrgico e à reabilitação.

Keywords: Articulação tibiotársica; Claudicação; Células totipotentes; Terapia coadjuvante.

\section{Resumen}

La ruptura de la cápsula articular en caballos es una enfermedad poco común que provoca dolor intenso y claudicación, afectando negativamente el performance de los equinos atletas. Esta enfermedad presenta protocolos terapéuticos controvertidos en clínica y cirugía equina. Por tanto, el objetivo es informar sobre el uso de células madre asociado a artroscopia y rehabilitación en el tratamiento de ruptura de la cápsula articular. Para ello, seguimos el caso de un equino cuarto de milla de tres años de edad que presenta claudicación severa con cuatro meses de evolución, siendo diagnosticado con ruptura de cápsula de la articulación tibiotarsiana. El paciente fue sometido a artroscopia e recibió aplicación intraarticular de células madre mesenquimales asociada a un protocolo de rehabilitación. Después de un año de tratamiento el paciente restablece el rendimiento atlético en baja intensidad, demostrando el éxito de la terapia con células madres mesenquimales asociada al tratamiento quirúrgico y de rehabilitación.

Palabras clave: Articulación tibiotarsiana; Claudicación; Células totipotentes; Terapia adyuvante.

\section{Introduction}

Articular capsule rupture and its extrusion to the interior of the joint is not a frequent pathology in equine medicine (Livesey et al., 2009). There are few therapeutic options for this condition and those that are available present low effectiveness for treating this condition (Barker et al., 2013; Mcilwraith et al., 2016).

The joint capsule rupture leads to increased articular volume and severe pain due to the vast number of sensitive receptors at the articular capsule (Mcilwraith et al., 2016). The advance of the condition can lead to lameness, as a result of chronic pain or, secondarily, to fibrosis formed by the healing process (Mcilwraith et al., 2016; Rich Redding, 2011). Mesenchymal stem cells (MSC) act in the repair of the articular capsule, improving the treatment by blocking the intra-articular inflammatory cycle, in addition to enhancing the healing of the injured structures (Broeckx et al., 2019; Taylor et al., 2007; Van Lent \& Van den Berg, 2013).

The current case report aims to describe the diagnosis, surgical treatment, and postoperative management of a 3-year-old horse presenting joint capsule rupture, which after the treatment, returned to perform at the same intensity as previously.

\section{Methodology}

The paper reports a case of articular capsule rupture in a horse by describing the treatment option used in the case; using the surgical approach described by McIlwraith et al. (2016), associated with the intraarticular stem cells injection technique described by Yamada et al. (2013); and presenting the results of the established treatment. This paper aims to expand the limited publish knowledge on an uncommon condition in equine orthopedics, while demonstrating the possible benefits of the use of mesenchymal stem cells associated with surgery as a potential treatment option.

\section{Case Report}

A 3-year-old, Quarter Horse, male gelding, suffered a non-perforating injury to the right hind limb during training. First aid care was given by a veterinarian who prescribed rifampin, amikacin, trimethoprim-sulfadiazine, and flunixin meglumine (dosages, routes, laboratories unknown). The owner reported initial improvement, but at the end of the treatment, the lameness increased. Therefore, euthanasia was recommended. 
Since the owner refused to perform the euthanasia, the horse was referred to the Large Animal Surgery Service of the FMVZ-HV-UNESP, four months after the injury. According to the owner, after the injury, the training was suspended and the horse was kept in a stall.

At admission, a complete physical exam was performed, and the clinical parameters were within the reference range for the species. The horse did not present any concomitant diseases. On visual inspection the horse presented grade 5 lameness (1-5 scale) (AAEP, 2018); the hock palpation revealed effusion at the tarsocrural (TC) joint, with normal temperature.

The radiographic evaluation revealed osteoarthritis (OA) of the proximal intertarsal (PIT) and distal intertarsal (DIT) joints, and of the tarsometatarsal (TMT) joint, in addition to osteochondritis dissecans (OCD) at the lateral trochlea of the talus (LTR) (Figure 1).

An ultrasonographic evaluation revealed rupture and intra-articular projection of a fragment of the joint capsule at the tarsocrural (TC) joint, near the lateral trochlea of the talus (LTR) (Figure $2 \mathrm{~A}$ and B).

The radiographic and ultrasonography evaluations revealed the rupture and intraarticular invagination of the articular capsule at the TC joint, along with osteoarthritis of the PIT, DIT, and MTM joints, and an OCD lesion at the lateral trochlea of the talus. Arthroscopic surgery was performed to remove the articular capsule fragment and to treat the OCD lesion. Before the procedure, a blood sample was taken, which revealed neutrophilia without leukocytosis.

Figure 1 - Radiographic image of the tarsal joints of the right hind limb. A: lateromedial view. b: dorsoplantar view. Bone proliferation can be observed in the area located dorsally to the central tarsal bone and the third tarsal bone. Articular collapse of the proximal and distal intertarsal joints. Sclerosis of the tarsal cuboid bones. Irregularity at the subchondral bone of the lateral trochlea of the talus.

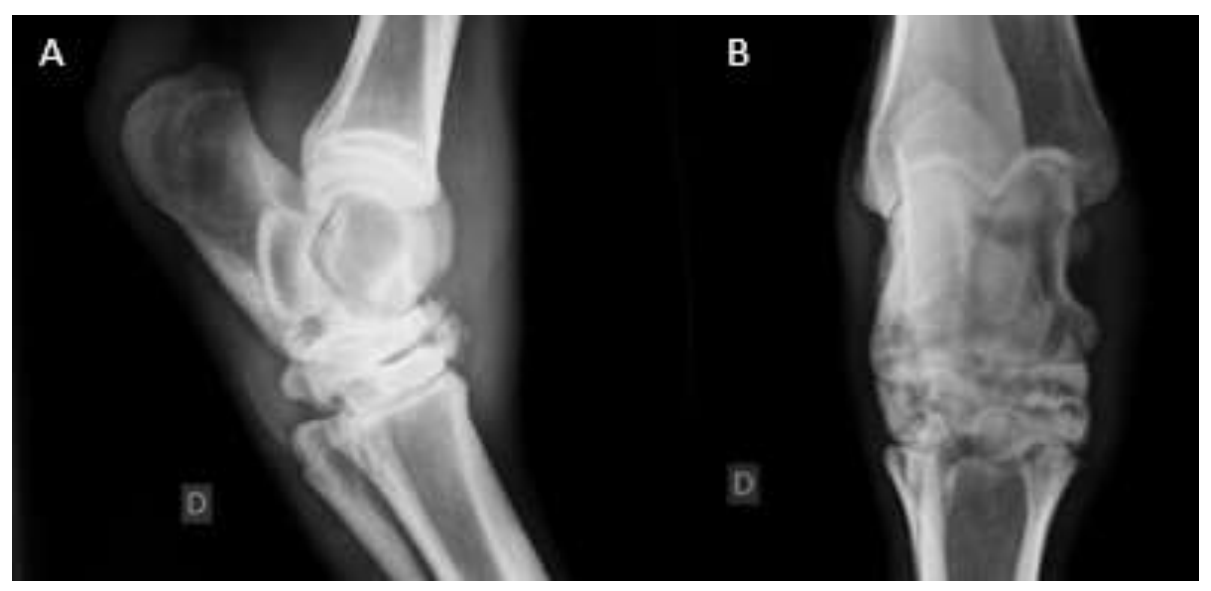

Source: Cestari et al. (2021).

A sample of the synovial fluid was submitted to cytological evaluation, culture, and an antibiogram. The evaluation indicated turbidity of the synovial fluid, 800 nucleated cells $/ \mu \mathrm{L}$ with the predominance of neutrophils; additionally, the bacterial culture was negative.

The arthroscopic surgery was performed in order to remove the articular capsule fragment insinuated inside the TC joint. A portion of the synovial membrane was collected to cultivate MSC. The intraarticular fragment of the articular capsule was submitted to histopathological evaluation which revealed chronic capsulitis and capsular epithelium hyperplasia. 
Figure 2 - Ultrasonographic image of the right hock. A: longitudinal hock view at the region of the LTR. Ultrasound presents anechoic synovial fluid ("x") and anechoic organized piece of tissue insinuated at the articular space (arrow). B: Visualization of the site of the joint capsule rupture. Large arrow: site of the rupture. Small arrow: piece of articular capsule insinuated at the interior of the articular compartment. Arrowhead: insertion of the invaginated joint capsule.
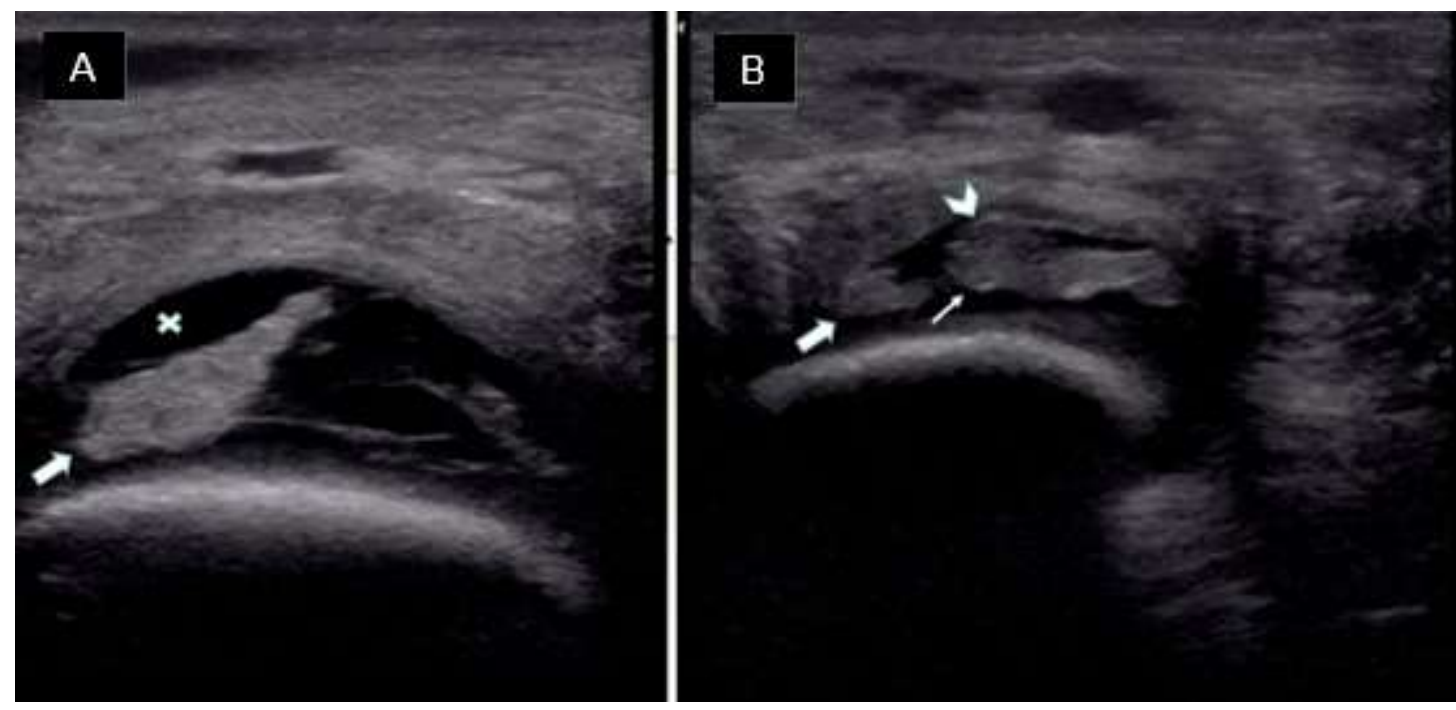

Source: Cestari et al. (2021).

An OCD lesion at the lateral trochlea of the talus, near the site of articular capsule rupture, was also treated arthroscopically. The excess of proliferated synovial membrane was removed using a shaver, and the joint was flushed at the end of the procedure (Figure 3). At the end of the surgery, morphine and amikacin were injected into the joint, $0.1 \mathrm{mg}$ and $250 \mathrm{mg}$ respectively.

The horse was also treated with ceftriaxone, $2 \mathrm{~g}$, by regional limb perfusion for 10 days; heparin, $80 \mathrm{IU} / \mathrm{Kg}$, SC, for 11 days; meloxicam, $0.6 \mathrm{mg} / \mathrm{Kg}, \mathrm{PO}$, once; and phenilbutazone $2.2 \mathrm{mg} / \mathrm{Kg}$ once then $4.4 \mathrm{mg} / \mathrm{Kg}$ for 4 days. In addition, the horse also received omeprazole, $2 \mathrm{mg} / \mathrm{Kg}$, $\mathrm{PO}$, for 19 days.

On the $25^{\text {th }}$ post-operative day, 10 million MSC were injected into the joint and a rehabilitation protocol was established using hand-walking and exercises to engage the TC joint. Ten days after the injection of MSC the horse started to show clinical improvement and a lower grade of lameness. On the $45^{\text {th }}$ post-operative day, the horse was discharged from the hospital presenting a lameness score of 3/5. A recommendation was given to keep resting and continue the rehabilitation protocol. One year after being discharged, the owner reported that the horse had returned to successfully performing low intensity exercises. 
Figure 3 - Arthroscopic images of the tarsocrural joint. A: image of the ruptured articular capsule into the articular space. B: arthroscopic debridement of the OCD lesion at the lateral trochlea of the talus and removal of proliferated synovial membrane.

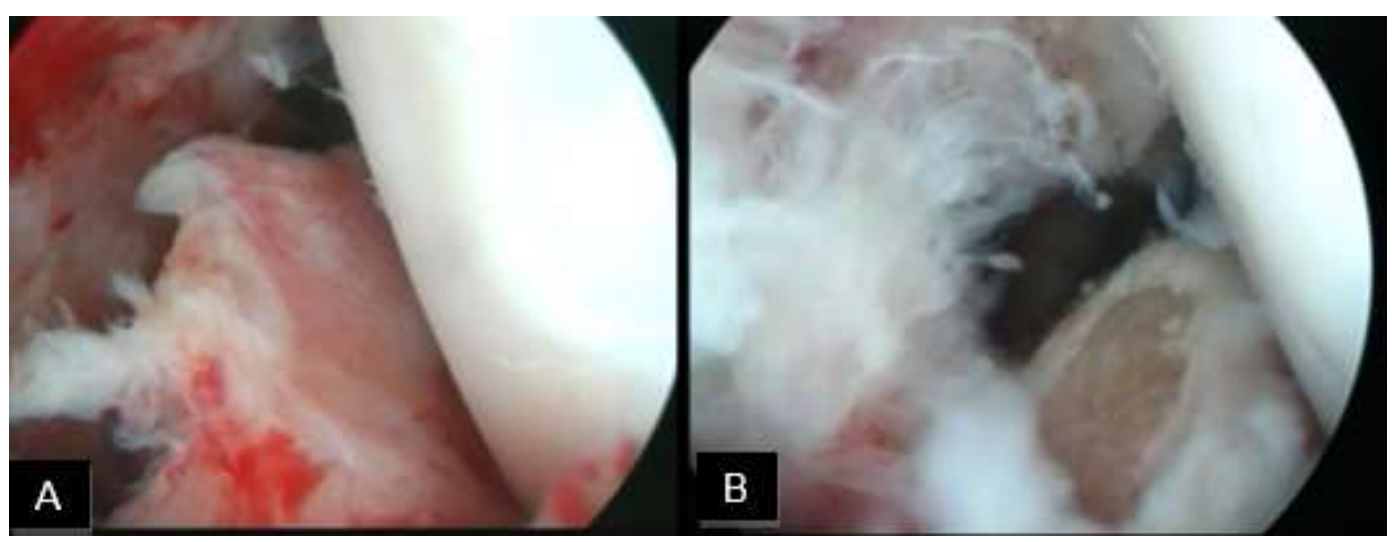

Source: Cestari et al. (2021).

\section{Discussion}

The articular capsule is composed of two layers, the outer layer, consisting of stiff fibrous tissue, with only proprioceptive innervation, and the inner layer, which is also composed by two layers, the subintimal layer, composed of loose connective tissue, and the synovial membrane itself, which has vast nociceptive innervation (Mcilwraith et al., 2016).

The synovial membrane receptors are sensitive to chemical, mechanical, and thermal variations. The chemical alterations, such as increased concentration of inflammatory mediators, exacerbate the response to mechanical stimuli, leading to hyperalgesia (Mcilwraith et al., 2016). Therefore, articular capsule rupture cases provoke intense pain.

Articular capsule diseases stimulate the secretion of enzymes, thus affecting all the intra-articular and periarticular structures (Mcilwraith et al., 2016). Additionally, lesions in the fibrous articular capsule result in increased ligament extension, and decreased articular stiffness and energy absorption during movement, reducing the flexibility of the articular capsule. Even minor traumas can predispose to injuries in the rest of the joint (Mcilwraith et al., 2016).

The pathogenesis of the articular capsule rupture is not entirely understood (Livesey et al., 2009; Mcilwraith et al., 2016). Articular capsule lesions present a challenge to the diagnosis and treatment. Without using magnetic resonance image, the injuries can be neglected in early stages, considering that radiographic findings are present only in chronic cases (Mcilwraith et al., 2016).

Bone proliferation (osteophytes and enthesophytes) occurs as a consequence of intraarticular bone injury (Butler et al., 2017), being the main finding in chronic cases of lesions to the articular capsule (Rich Redding, 2011). In humans, traumatic events lead to bone; which in turn, leads to the development of OA (Boller \& Lopes, 2021; Livesey et al., 2009; Mcilwraith et al., 2016). However, the hypothesis that the OA present in the other joints of the tarsus is an independent disease cannot be dismissed, since important information is missing regarding the accurate origin of the lesion and previous treatments performed on the horse prior to the referral to HV-UNESP.

The radiographic findings in the DIT and TMT joint - bone proliferation, narrowing of the articular space - possibly resulted in the articular capsule rupture response, in an attempt to stabilize the joint, through ankylosis (Bussoni \& Audigié, 2018). If the injury were restricted to a single bone or tarsal joint, a septic disease would be more likely (Bussoni \& Audigié, 2018; Butler et al., 2017). Nevertheless, it is not possible to guarantee a relation between these injuries and to blame the articular instability on the articular capsule rupture. 
Research, Society and Development, v. 10, n. 12, e211101220370, 2021

(CC BY 4.0) | ISSN 2525-3409 | DOI: http://dx.doi.org/10.33448/rsd-v10i12.20370

The treatment for cases of articular capsule rupture includes the removal of the ruptured portion of the capsule for the formation of an inert tissue and healing by second intention (Barker et al., 2013). However, there is no scientific evidence supporting the effectiveness of the treatment when used in isolation, since in the published reports, other rehabilitation protocols, such as physiotherapy, were also performed. Therefore, there are no clinical trials treating this lesion with only arthroscopy (Barker et al., 2013).

In the present case, the treatment aimed to remove the tissue inside the joint and to form a scar. In addition to the surgical treatment, rehabilitation protocols using controlled exercises and treatment with MSC were also performed.

Synovial macrophages contribute to the destruction of articular cartilage by releasing pro-inflammatory factors such as interleukin 1 (IL-1) and/or transforming growth factor $\beta$ (TGF $\beta$ ), which is crucial for the formation of osteophytes. Consequently, damage to articular cartilage by inflammation or bone proliferation leads to the release of cartilage fragments into the articular space, producing positive feedback for the release of synovial macrophages. This, in turn, increases the articular damage, and possibly leads to OA (Cunha \& Silva, 2021; Van Lent \& Van den Berg, 2013).

The intraarticular injection of MSC is capable of reducing the activation of synovial macrophages, resulting in the inhibition of cartilage destruction and the formation of osteophytes (Broeckx et al., 2019; Cunha \& Silva, 2021; Van Lent \& Van den Berg, 2013; Yamada et al., 2013). Furthermore, when injected into the intraarticular space, the MSC is able to populate the articular surface and synovial membrane (Mcilwraith et al., 2016; Taylor et al., 2007). As a result, MSC can be used in tissue repair of cartilaginous structures, subchondral bone, and in articular capsule lesions, as it blocks the intraarticular inflammatory cycle, through the expression of anti-inflammatory molecules.

The previous statements support the use of MSC, as this treatment has the potential to aid the reparation process at the articular capsule rupture site, and the formation of a new cartilaginous matrix in the treated OCD lesion. In addition, MSC reduces the progression of the cartilage destruction and the formation of osteophytes, both found in the present case.

The beneficial effects of MSC are not restricted to the site of the injection, the TC joint, since there is communication between this and the PIT joint (Mcilwraith et al., 2016). Nonetheless, the clinical improvement seen in the present case cannot be attributed solely to the MSC treatment, because other treatment modalities were used simultaneously.

\section{Conclusion}

Articular capsule rupture is a poorly reported disease, for which there is no well-established treatment protocol. Therapeutic management using mesenchymal stem cells, arthroscopy and physiotherapy showed good results in the present case, and could be an option in other cases. Further studies are necessary to determine the negative effects of the articular capsule rupture in the articular structures, in order to provide a better knowledge of the pathologies associated with the progression of this condition, allowing the development of a well-rounded protocol for the cases, and confirming the effects of MSC in these types of lesions, in order to, establish a treatment option that will enhance the healing and rehabilitation of future cases.

\section{References}

AAEP, A. A. of E. P. (2018). LAMENESS EXAMS: Evaluating the Lame Horse. https://aaep.org/horsehealth/lameness-exams-evaluating-lame-horse

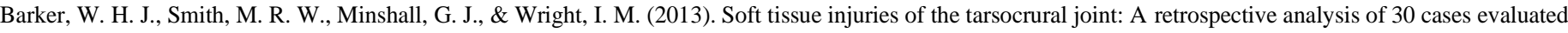
arthroscopically. Equine Veterinary Journal, 45(4), 435-441. https://doi.org/10.1111/j.2042-3306.2012.00685.x

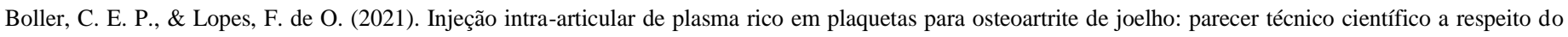


Research, Society and Development, v. 10, n. 12, e211101220370, 2021

(CC BY 4.0) | ISSN 2525-3409 | DOI: http://dx.doi.org/10.33448/rsd-v10i12.20370

uso. Research, Society and Development, 10(1), e15710111606. https://doi.org/10.33448/rsd-v10i1.11606

Broeckx, S. Y., Seys, B., Suls, M., Vandenberghe, A., Mariën, T., Adriaensen, E., Declercq, J., Van Hecke, L., Braun, G., Hellmann, K., \& Spaas, J. H. (2019). Equine Allogeneic Chondrogenic Induced Mesenchymal Stem Cells Are an Effective Treatment for Degenerative Joint Disease in Horses. Stem Cells and Development, 28(6), 410-422. https://doi.org/10.1089/scd.2018.0061

Bussoni, V., \& Audigié, F. (2018). Equine stifle and tarsus. In Textbook of Veterinary Diagnostic Radiology (Elsevier, p. 1000).

Butler, J. A., Colles, C. M., Dyson, S. J., Kold, S. E., \& W., P. P. (2017). Clinical Radiology of the Horse. In Wiley Blackwell (Issue 4). https://doi.org/10.1017/CBO9781107415324.004

Cunha, P. F. A., \& Silva, R. B. B. da. (2021). Osteoartrite de joelho e o aspirado de medula óssea como escolha de tratamento - Uma revisão narrativa. Research, Society and Development, 10(7), e17410716391. https://doi.org/10.33448/rsd-v10i7.16391

Livesey, L., Schumacher, J., Sartin, E., Caldwell, M., Ziska, S., \& Brock, K. (2009). Ruptured capsule of the elbow joint of a draught horse. Equine Veterinary Education, 21(7), 371-374. https://doi.org/10.2746/095777309X422988

Mcilwraith, C. W., Frisbie, D., Kawcak, C., \& Weeren, R. V. (2016). Joint disease in the horse. In Journal of Equine Veterinary Science (Issue 9). https://doi.org/10.1016/s0737-0806(96)80178-x

Rich Redding, W. R. (2011). Ultrasound. In Lameness in horse (Sixth, pp. 338-376).

Taylor, S. E., Smith, R. K. W., \& Clegg, P. D. (2007). Mesenchymal stem cell therapy in equine musculoskeletal disease: Scientific fact or clinical fiction? Equine Veterinary Journal, 39(2), 172-180. https://doi.org/10.2746/042516407X180868

Van Lent, P. L. E. M., \& Van den Berg, W. B. (2013). Mesenchymal stem cell therapy in osteoarthritis: Advanced tissue repair or intervention with smouldering synovial activation? Arthritis Research and Therapy, 15(2), 1-2. https://doi.org/10.1186/ar4190

Yamada, A. L. M., Carvalho, A. de M., Moroz, A., Deffune, E., Watanabe, M. J., Hussni, C. A., Rodrigues, C. A., \& Alves, A. L. G. (2013). Mesenchymal stem cell enhances chondral defects healing in horses. Stem Cell Discovery, 03(04), 218-225. https://doi.org/10.4236/scd.2013.34027 